JKM (Jurnal Kebidanan Malahayati),Vol 7,No.3.Juli 2021,

ISSN (Print) 2476-8944 ISSN (Online) 2579-762X, Hal 391-397

\title{
EFEKTIFITAS PENDIDIKAN KESEHATAN TENTANG TOKSOPLASMOSIS TERHADAP PENINGKATAN PENGETAHUAN DAN SIKAP WANITA USIA SUBUR (WUS)
}

\author{
Nurdahliana ${ }^{1}$, Noviyanti $^{2}$ \\ 1 Jurusan Kebidanan Poltekkes Kemenkes Aceh \\ 2Program Studi D-IV Kebidanan Poltekkes Kemenkes Aceh \\ Email : nurdahliana1969@gmail.com, noviyanti@poltekkesaceh.ac.id \\ *Korespondensi
}

\section{ABSTRACT THE EFFECTIVENESS OF HEALTH EDUCATION ABOUT TOXOPLASMOSIS ON INCREASING KNOWLEDGE AND ATTITUDE OF WOMEN OF RELIABLE AGE (WUS)}

Background: In general, Toxoplasma infection does not cause any symptoms, but in pregnant women the infection can risk the placenta and the baby. In the long term, babies can grow up to be blind, deaf, decreased IQ and mentally retarded. 3

Purpose was to determine the effectiveness of Toxoplasmosis Health Education on Increasing Knowledge and Attitudes of Fertile Age Women (WUS) in Gampong Lampoh Keude, Kuta Baro District, tofu.

Methods: The design of this study used a quasi-experimental (quasi-experimental) design with a nonrandomized pretest-posttest only control group design. The sample was women of childbearing age taken by purposive sampling of 40 people (lecture group of 20 people and leaflet group of 20 people). Then the data were analyzed by univariate and bivariate, using the statistical test is the $t$ test.

Results: There was no significant increase in the knowledge of respondents in the lecture and leaflet groups with a sign value of 0.289 (sign $\square 0.05$ ). And the attitude of the respondents in the lecture group and the leaflet group did not have any significant changes with a sign value of 1,000 (sign $\square 0.05$ ).

Conclusion: there is a change in respondent's knowledge and respondent's attitude there is no change in health education using leaflets and lectures

Suggestion: WUS is expected to maintain health and live a healthy life so as not to contract toxoplasmosis infection, before or during pregnancy.

Keywords: Toxoplasmosis, women of childbearing age, knowledge and attitudes.

\section{ABSTRAK}

Latar Belakang : Pada umumnya infeksi toksoplasma tidak menimbulkan gejala apa pun, namun pada ibu hamil infeksi tersebut dapat berisiko menyerang plasenta dan bayi. Dalam jangka panjang, bayi dapat tumbuh menjadi anak yang buta, tuli, penurunan $I Q$ dan terbelakang mental. ${ }^{3}$

Tujuan: mengetahui Efektifitas Pendidikan Kesehatan Toksoplasmosis terhadap Peningkatan Pengetahuan dan Sikap Wanita Usia Subur (WUS) di Gampong Lampoh Keude kecamatan Kutabaro.

Metode : Desain penelitian ini menggunakan quasi eksperimental (eksperimen semu) dengan rancangan nonrandomized pretest-posttest only control group design. Sampel adalah wanita usia subur diambil secara purposive sampling sebanyak 40 orang (kelompok ceramah 20 orang dan kelompok leaflet 20 orang). Kemudian data dianalisis secara univariat dan bivariat, dan menggunakan uji statistik adalah $t$ test.

Hasil : Pengetahuan responden pada kelompok ceramah dan kelompok leaflet tidak ada peningkatan yang bermakna dengan nilai sign 0,289 ( sign $>0,05$ ). Sikap responden pada kelompok ceramah dan kelompok leaflet tidak ada perubahan yang bermakna dengan nilai sign 1,000 ( $\operatorname{sign}>0,05)$.

Kesimpulan : ada perubahan pengetahuan responden dan sikap responden, namun tidak ada perubahan pendidikan kesehatan penggunaan leafllet dan ceramah.

Saran: Kepada WUS diharapkan menjaga kesehatan dan hidup sehat supaya tidak terjangkit infeksi toksoplasmosis, sebelum ataupun ketika hamil.

Kata Kunci : Toksoplasmosis, wanita usia subur, pengetahuan dan sikap. 


\section{Nurdahliana, Noviyanti}

\section{PENDAHULUAN}

Toksoplasmosis yaitu penyakit infeksi yang disebabkan oleh protozoa Toxoplasma gondii, yang merupakan parasit obligat intraselular yang memiliki siklus hidup kompleks pada hewan berdarah panas. Manusia merupakan hospes perantara bagi parasit ini dan kucing sebagai hospes definitif. Protozoa Toxoplasma gondii pertama sekali ditemukan tahun 1908 pada hewan pengerat Ctenodactylus gondii oleh Nicole dan Manceaux (Galvan-Ramirez, 2012) dan (Triana, 2015). Salah satu penyebab infeksi TORCH adalah Toxoplasma gondii. Pada ibu hamil kondisi ini dapat menyerang janin dan bayi baru lahir (Suparman, 2012) dan (Aryani, 2017). Walaupun penyakit parasit ini berbahaya namun bisa dicegah (Andiappan, 2014) dan (Sari, 2017).

Umumnya infeksi toksoplasmosis bersifat jinak dan asimtomatik, toksoplasmosis menyebabkan komplikasi utama pada individu dengan gangguan sistem imun dan selama kehamilan. Tindakan pencegahan tergantung pada pengetahuan wanita tentang toksoplasmosis (Smereka, 2018) dan (Agustis, 2015). Pada umumnya infeksi toksoplasma tidak menimbulkan gejala apa pun, namun pada ibu hamil infeksi tersebut dapat berisiko menyerang plasenta dan bayi. Meskipun hanya sekitar 1 dari 10.000 bayi terkena toksoplasmasis, namun infeksi tersebut perlu diwaspadai (Runtukahu, 2021) dan (Iskandar, 2018). Infeksi toksoplasma pada bayi (congenital toxoplasmosis) dapat menyebabkan gangguan fungsi otak, mata, ginjal, jantung, fungsi hati dan lainnya (Marthalia, 2020) dan (Oktariana, 2014). Dalam jangka panjang, bayi dapat tumbuh menjadi anak yang buta, tuli, penurunan IQ dan terbelakang mental (Basri, 2017) dan (Sari, 2019). Sekitar $10-15 \%$ wanita hamil memiliki kekebalan alami terhadap toksoplasmosis karena dalam tubuhnya telah terbentuk serum antibodi dari infeksi sebelumnya. Sejumlah lainnya yang tidak memiliki kekebalan memang rentan terkena, namun kemungkinan terinfeksi juga biasanya rendah (Andriyani, 2015).

Untuk menunjang pelaksanaan penelitian ini, peneliti mendapatkan data dari Puskesmas Kuta Baro tentang kejadian pada ibu dan anak berkaitan dengan terjangkit toksoplasmosis yaitu ibu abortus berulang 8 orang, bayi lahir meninggal dengan kondisi ensephalo 3 orang, anak-anak mengalami (autis, juling, bisu, retardasi mental, gangguan motorik) sekitar 46 orang, dan dari cerita bidan ada ibu-ibu mengeluh belum hamil sudah menikah diatas 3 tahun di khawatirkan terjangkit penyakit toksoplasmosis. Hasil wawancara dari 10 orang
WUS menyatakan bahwa 6 orang tidak mengetahui tentang toksoplasmosis, dan 4 orang pernah mendengar tentang toksoplasmosis. Data dari Puskesmas Kuta Baro tentang jumlah WUS sebanyak 5.213 dalam 47 desa. Adapun WUS di Gampong Lampoh Keude adalah 163 orang.

Berdasarkan uraian diatas maka peneliti tertarik untuk melakukan penelitian dengan judul Efektifitas Pendidikan Kesehatan Toksoplasmosis terhadap Peningkata Pengetahuan dan Sikap Wanita Usia Subur (WUS). Tujuan penellitian untuk mengetahui Efektifitas Pendidikan Kesehatan Toksoplasmosis terhadap Peningkatan Pengetahuan dan Sikap Wanita Usia Subur (WUS) di Gampong Lampoh Keude kecamatan Kuta Baro

\section{METODOLOGI PENELITIAN}

Desain penelitian ini menggunakan quasi eksperimental (eksperimen semu) dengan rancangan nonrandomized pretest-posttest only control group design. Penelitian ini dilaksanakan di Gampong Lampoh Keude. Populasi adalah keseluruhan subjek penelitian. Populasi dalam penelitian ini adalah wanita usia subur (WUS) di Gampong Lampoh Keudee tahun 2016, yang berjumlah 173 orang.

Sampel diambil secara purposive sampling yang memenuhi kriteria inklusi, dan di bagi dalam dua kelompok yaitu kelompok ceramah 20 orang dan kelompok leaflet 20 orang. Dalam penentuan sampel dengan kriteria inklusi adalah: 1. WUS, 2. Bersedia menjadi responden, 3. Sudah menikah; dan kriteria eksklusi adalah 1. Dalam keadaan sakit, 2. Penduduk tidak tetap.

Pelaksanaan penelitian berlangsung selama \pm 4 bulan, mulai pelaksanaan dari bulan Agustus sampai November 2016 di Gampong Lampoh Keude kecamatan Kuta Baro kabupaten Aceh Besar. Untuk pre-test dilaksanakan bulan Agustus 2016 dengan jumlah responden kelompok ceramah 20 orang terpenuhi, tetapi kelompok leafleat dari 20 orang hanya datang 9 orang. Supaya terpenuhi jumlah kelompok leafleat maka dilakukan door to door di Gampong Lampoh Keude.selama 3 hari. Langkah ini di bantu oleh enumerator yang sudah peneliti ikut sertakan dari awal penelitian ini. Sebelum pre-test enumerator menjaring calon responden sesuai kriteria yang peneliti tetapkan dan memberi surat pernyataan kesediaan jadi responden.

Kemudian peneliti melakukan post-test di bulan November 2016, tetapi masih juga terkendala oleh tidak terpenuhi jumlah responden pada hari yang telah disepakati sebelumnya. Adapun kendala pada hari itu adalah ada acara di desa lampoh 
Keude maka ibu-ibu berhalangan hadir, juga sebagian turun ke sawah, dan ada juga tidak di tempat. Untuk terpenuhi jumlah post test maka peneliti dan di bantú oleh enumerator melakukan kinjungan rumah. Tetapi sampai waktu yang peneliti tetapkan untuk post test tidak dapat berjalan dengan baik karena ibu-ibu yang sudah dijadikan responden tidak di tempat. Peneliti harus menunggu lagi waktu yang lain untuk bertemu dengan responden.

\section{HASIL DAN PEMBAHASAN}

Penelitan dilaksanakan di gampong lampoh keudeu kecamatan kuta baro kabupaten Aceh Besar.
Berdasarkan tabel 1 menunjukkan bahwa dari 20 responden terdapat pengetahuan baik sebelum menerima pendidikan kesehatan pada kelompok ceramah berjumlah 15 orang $(75 \%)$, dan setelah menerima pendidikan kesehatan pengetahuan baik jadi 20 orang (100\%). Untuk kelompok leaflet yang pengetahuan baik sebelum menerima pendidikan kesehatan berjumlah 18 orang $(90 \%)$, dan responden pengetahuan baik setelah menerima pendidikan kesehatan berjumlah 19 orang $(95 \%)$.

\section{Analisa Univariat}

Tabel 1.

Distribusi Frekuensi Pengetahuan WUS Pada Pre-Post Ceramah dan Leaflet

\begin{tabular}{lcccccccc}
\hline & \multicolumn{9}{c}{ Pendidikan Kesehatan } \\
\cline { 2 - 9 } Pengetahuan & \multicolumn{3}{c}{ Pre-test } & \multicolumn{4}{c}{ Post-test } \\
\cline { 2 - 9 } & \multicolumn{2}{c}{ Ceramah } & \multicolumn{2}{c}{ Leaflet } & \multicolumn{2}{c}{ Ceramah } & \multicolumn{2}{c}{ Leaflet } \\
\cline { 2 - 9 } & $\mathbf{n}$ & $\%$ & $\mathbf{n}$ & $\%$ & $\mathbf{n}$ & $\%$ & $\mathbf{n}$ & $\%$ \\
\hline Cukup & 5 & 25 & 2 & 10 & 0 & 0 & 1 & 5 \\
Baik & 15 & 75 & 18 & 90 & 20 & 100 & 19 & 95 \\
\hline \multicolumn{1}{c}{ Total } & 20 & 100 & 20 & 100 & 20 & 100 & 20 & 100 \\
\hline
\end{tabular}

Tabel 2.

Distribusi Frekuensi Sikap WUS Pada Pre-Post Ceramah Dan Leaflet

\begin{tabular}{lcccccccc}
\hline & \multicolumn{9}{c}{ Pendidikan Kesehatan } \\
\cline { 2 - 9 } \multicolumn{1}{c}{ Sikap } & \multicolumn{3}{c}{ Pre-test } & \multicolumn{4}{c}{ Post-test } \\
\cline { 2 - 10 } & \multicolumn{2}{c}{ Ceramah } & \multicolumn{2}{c}{ leaflet } & \multicolumn{2}{c}{ Ceramah } & \multicolumn{2}{c}{ Leaflet } \\
\cline { 2 - 10 } & $\mathbf{n}$ & $\%$ & $\mathbf{n}$ & $\%$ & $\mathbf{n}$ & $\%$ & $\mathbf{n}$ & $\%$ \\
\hline Negatif & 0 & 0 & 0 & 0 & 0 & 0 & 0 & 0 \\
Positif & 20 & 100 & 20 & 100 & 20 & 100 & 20 & 100 \\
\hline Total & 20 & 100 & 20 & 100 & 20 & 100 & 20 & 100 \\
\hline
\end{tabular}

Berdasarkan tabel 2 menunjukkan bahwa dari 20 responden terdapat sikap positif sebelum dan sesudah menerima pendidikan kesehatan pada kelompok ceramah berjumlah sama yaitu 20 orang $(100 \%)$. Demikian juga pada kelompok leaflet yang sikap positif sebelum dan sesudah menerima pendidikan kesehatan juga berjumlah sama yaitu 20 orang (100\%).

\section{Analisa Bivariat}

\section{Pengetahuan WUS pada Pre-Post Tetst Dengan Leaflet dan Ceramah}

Berdasarkan tabel 3 dapat diketahui bahwa pengetahuan WUS pre-test dan post-test pada kelompok leaflet tidak ada perubahan yang bermakna dengan nilai sign 0,317 (sign $>0,05)$. Untuk pengetahuan WUS pre-test dan post-test pada kelompok ceramah ada perubahan yang bermakna dengan nilai sign 0,025 (sign $<0,05$ ).

Berdasarkan tabel 4 dapat diketahui bahwa sikap WUS pre-test dan post-test pada kelompok leaflet tidak ada perubahan yang bermakna dan memiliki nilai signifikan yang sama yaitu sign 1,000 $(\operatorname{sign}>0,05)$. 
Hasil Uji Wilcoxon Kelompok Leaflet dan Ceramah terhadap Pengetahuan WUS

\begin{tabular}{lcccc}
\hline \multirow{2}{*}{ Pengetahuan } & \multicolumn{2}{c}{ Leaflet } & \multicolumn{2}{c}{ Ceramah } \\
\cline { 2 - 5 } & Mean & \multicolumn{3}{c}{ Mean } \\
& Rank & Sign & Rank & Sign \\
\hline Pre-Test \& & 1,00 & 0,317 & 3,00 & 0,025 \\
Post-Test & 1,00 & \\
\hline
\end{tabular}

\section{Sikap WUS pada Pre-Post Test dengan Leaflet} dan Ceramah

Tabel 4.

Hasil Uji Wilcoxon Kelompok Leaflet dan Ceramah terhadap Sikap WUS

\begin{tabular}{lcccc}
\hline \multirow{2}{*}{ Pengetahuan } & \multicolumn{2}{c}{ Leaflet } & \multicolumn{2}{c}{ Ceramah } \\
\cline { 2 - 5 } & $\begin{array}{l}\text { Mean } \\
\text { Rank }\end{array}$ & Sign & $\begin{array}{l}\text { Mean } \\
\text { Rank }\end{array}$ & Sign \\
\hline $\begin{array}{l}\text { Pre-Test \& } \\
\text { Post-Test }\end{array}$ & 0,00 & 1,000 & 0,00 & 1,000 \\
\hline
\end{tabular}

\section{Efektifitas Pendidikan Kesehatan Terhadap Pengetahuan dan Sikap WUS}

Tabel 5.

Hasil Uji Mann-Whitney Kelompok Leaflet dan Ceramah terhadap Pengetahuan dan Sikap WUS

\begin{tabular}{llccc}
\hline \multirow{2}{*}{$\begin{array}{l}\text { Pendidikan } \\
\text { Kesehatan }\end{array}$} & \multicolumn{2}{c}{ Pengetahuan } & \multicolumn{2}{c}{ Sikap } \\
\cline { 2 - 5 } & $\begin{array}{l}\text { Mean } \\
\text { Rank }\end{array}$ & Sign & $\begin{array}{l}\text { Mean } \\
\text { Rank }\end{array}$ & Sign \\
\hline Leaflet & 18,50 & 0,289 & 20,50 & 1,000 \\
Ceramah & 22,50 & 0,50 & 20,50 \\
\hline
\end{tabular}

Berdasarkan tabel 5 dapat diketahui bahwa pengetahuan responden pada kelompok ceramah dan kelompok leaflet tidak ada peningkatan yang bermakna dengan nilai sign 0,289 (sign $>0,05$ ). Untuk sikap responden pada kelompok ceramah dan kelompok leaflet tidak ada juga perubahan yang bermakna dengan nilai sign 1,000 (sign > $0,05)$.

\section{PEMBAHASAN}

Hasil penelitian dapat diketahui bahwa pengetahuan responden pada kelompok ceramah dan kelompok leaflet tidak ada peningkatan yang bermakna dengan nilai sign 0,289 (sign $>0,05$ ). Pendidikan kesehatan yang baik dapat meningkatkan pengetahuan. Pengetahuan yang bagus, cenderung memiliki resiko yang rendah terinfeksi parasit dibandingkan dengan responden yang memiliki pengetahuan yang rendah (Guo,
2017). Penelitian yang dilakukan oleh Amaliah et al (2014) menunjukkan bahwa metode diskusi lebih baik daripada metode ceramah, demikian juga dengan penelitian yang dilakukan oleh Wijaya (2016) yang menyatakan bahwa metode Studen Teams Achievement Division lebih baik dari pada metode ceramah (Amaliah, 2014) dan (Wijaya, 2016).

Penelitian ini sejalan dengan penelitian Laboudi (2014), menyebutkan paritas counfounding dengan kebiasaan menyentuh tanah dapat dilihat dari hasil penelitian bahwa 19 orang $(63,3 \%)$ ibu dengan toksoplasmosis dan 6 orang $(20 \%)$ memiliki kebiasaan menyentuh tanah, hal ini dapat disebabkan karena kurangnya pengetahuan tentang penyakit ini dan adanya hubungan toksoplasmosis terutama dengan aktivitas kebiasaan menyentuh tanah. Juga di dukung oleh hasil penelitian Wulandari (2020), didapatkan pengetahuan responden meningkat setelah diberikan pendidikan kesehatan menggunakan media leaflet sebesar $50 \%$ pengetahuan baik dan $50 \%$ pengetahuan cukup. Hasil penelitian ini di dukung juga oleh Fatmawati (2017), diketahui gambaran pengetahuan responden terjadi peningkatan pengetahuan sebelum dan sesudah diberikan pendidikan kesehatan dengan media leaflet tentang penatalaksanaan ISPA pada balita di Posyandu Bambu Kuning yaitu dari pengetahuan baik pretest $60 \%$ menjadi 95\% responden berpengetahuan baik.

Penelitian yang dilakukan Andiappan (2014) pada ibu hamil tentang toksoplasmosis adalah pengetahuan, kesadaran dan pendidikan kesehatan tentang infeksi parasit pada wanita hamil akan mencegah penularan penyakit serta melindungi janin atau bayi yang baru lahir dari infeksi tersebut. Hasil uji statistik Wilcoxon bernilai $0.0001<$ a 0.05 , menunjukkan bahwa ada perbedaan antara sebelum dan sesudah diberikan konseling. Artinya terdapat pengaruh konseling tentang Penyakit TORCH terhadap tingkat pengetahuan ibu hamil di wilayah kerja Puskesmas Sedayu II. Pengetahuan yang berhubungan dengan masalah kesehatan akan mempengaruhi terjadinya gangguan kesehatan pada kelompok tertentu. Kurangnya pengetahuan tentang suatu penyakit akan mengakibatkan berkurangnya kemampuan untuk mencegah dan menangani penyakit tersebut secara tepat (Notoadmojo, 2014). Hasil penelitian ini sejalan dengan penelitian yang menemukan bahwa pendidikan kesehatan di anjurkan untuk diberikan secara konsisten kepada wanita usia subur. Hal ini bertujuan untuk mengurangi penularan infeksi (Andiappan, 2014). 


\section{JKM (Jurnal Kebidanan Malahayati),Vol 7,No.3.Juli 2021, ISSN (Print) 2476-8944 ISSN (Online) 2579-762X, Hal 391-397}

Peneliti berasumsi dengan memberikan pendidikan kesehatan atau konseling pada WUS sebagai calon ibu hamil sangatlah penting. Setelah peneliti memberikan pendidikan kesehatan pada dua kelompok yaitu ceramah dan leaflet, walaupun terdapat nilai tidak ada peningkatan yang bermakna tetapi secara individual melalui metode ceramah responden lebih mudah memahami materi tentang toksoplasmosis. Ibu-ibu lebih antusias bertanya tentang materi yang disampaikan melalui ceramah dari pada kelompok leaflet. Pengetahuan WUS posttest dan pretest pada kelompok ceramah ada perubahan yang bermakna di bandingkan dengan kelompok leaflet. Tentang ini sejalan dengan penelitian yang membuktikan bahwa metode ceramah efektif dalam meningkatkan pengetahuan masyarakat terhadap penyakit tuberkulosis. Hal ini dibuktikan dengan terjadinya peningkatan nilai post tes jika dibandingkan dengan nilai pre tes setelah dilakukan perlakuan berupa ceramah dengan $p=$ 0,000 (Jatmiko, 2016), dan penelitian Guspita (2017) diketahui bahwa metode ceramah sangatlah efektif dilaksanakan sebagai metode penyuluhan.

Hasil penelitian dapat diketahui bahwa sikap responden pada kelompok ceramah dan kelompok leaflet tidak ada perubahan yang bermakna sebab nilai sign 1,000 (sign $>0,05$ ). Responden memiliki nilai sikap positif sebelum dan setelah di berikan ceramah, juga setelah membaca leaflet. Antara ceramah dan leaflet tidak ada perubahan sikap responden yang signifikan pada pre test dan post test. Artinya sama efektif bila diberikan pendidikan kesehatan melalui ceramah atau leaflet. Penelitian ini berbanding terbalik dengan penelitian Lubis (2016).

Peneliti berasumsi jika sikap responden baik dan berada pada tingkatan 4 yaitu bertanggung jawab (responsible), merupakan sikap yang paling tinggi tingkatnya. Seseorang yang telah mengambil resiko bila ada orang lain yang mencemoohkan atau adanya resiko lain. Maka ibu-ibu dan calon ibu bisa menjadi agen untuk perubahan gaya hidup, sehingga dapat menurunkan angka kesakitan akibat terinfeksi toksoplasma. Responden bisa menerima dan akan mengaplikasikan beberapa hal yang telah di ketahui tentang bahaya toksoplasmosis. Ibu-ibu menyatakan tidak lagi membiarkan air di ember terbuka sehingga mudah terjangkau oleh kucing. Juga anak-anak sudah dilarang untuk mencium kucing karena ditakutkan terjangkit penyakit toksoplasmosis, memasak daging tidak setengah matang, mengurangi makan sate, lalapan mentah, jika memelihara kucing akan di kontrol kesehatan ke dokter hewan dan lain sebagainya (Iskandar, 2014) dan (Febianingsih, 2017).

Penelitian ini sejalan dengan hasil penelitian Anggreni (2017), yaitu tidak terdapat hubungan yang signifikan antara tingkat pengetahuan terhadap perilaku pencegahan dan terdapat hubungan yang siginfikan antara sikap terhadap perilaku pencegahan di wilayah kerja Puskesmas Blahbatuh I dari 75 ibu hamil. Demikian pula dengan penelitian Safitri (2016), terdapat perbedaan rerata pengetahuan dan sikap gizi pada kelompok ceramah dan booklet $(p=0,05)$, dan pada penelitian Kurniawan et.al., 2020, menemukan perbedaan pengetahuan dan sikap ibu tentang toksoplasmosis di Puskesmas Kemiling dan klinik spesialis kandungan di bandar lampung.

\section{SIMPULAN}

Pengetahuan responden pada kelompok ceramah dan leaflet tidak ada peningkatan yang bermakna, juga Sikap responden pada kelompok ceramah dan leaflet tidak ada perubahan yang bermakna. Metode ceramah dan leafleat sama efektif dalam penyampaian pendidikan kesehatan kepada WUS.

\section{SARAN}

Kepada WUS diharapkan menjaga kesehatan dan hidup sehat supaya tidak terjangkit infeksi toksoplasmosis, sebelum ataupun ketika hamil.

\section{DAFTAR PUSTAKA}

Agustin, P. D., \& Mukono, J. (2015). Description Between Cats Exposure with Toxoplasmosis Disease on Cats Owner and Not-Cats Owner in Mulyorejo Subdistrict, Surabaya City. Jurnal Kesehatan Lingkungan, 8(1), 103-117.

Amaliah R R., Fadhil A., Narulita S. (2014). Penerapan Metode Ceramah dan Diskusi Dalam Meningkatkan Hasil Belajar PAI di SMA Negeri 44 Jakarta. Jurnal Studi AlQur'an;10(2):119-31

Andiappan, H., Nissapatorn, V., Sawangjaroen, N., Khaing, S. L., Salibay, C. C., Cheung, M. M. M., \& Mat Adenan, N. A. (2014). Knowledge and practice on Toxoplasma infection in pregnant women from Malaysia, Philippines, and Thailand. Frontiers in microbiology, 5 , 291.

Andiappan, H., Nissapatorn, V., Sawangjaroen, N., Nyunt, M. H., Lau, Y. L., Khaing, S. L., \& bin Mat Adenan, N. A. (2014). Comparative study on Toxoplasma infection between 


\section{Nurdahliana, Noviyanti}

Malaysian and Myanmar pregnant women. Parasites \& vectors, 7(1), 1-8.

Andriyani, R., \& Megasari, K. (2015). Faktor Risiko yang Berhubungan dengan Kejadian Infeksi Toksoplasma pada Ibu Hamil di RSUD Arifin Achmad Pekanbaru Tahun 2010-2013. Jurnal Kesehatan Andalas, 4(2).

Anggraini N, Kurniati YPD, \& Subrata Ml,. 2017. Hubungan Tingkat Pengetahuan dan Sikap Ibu Hamil Terhadap Perilaku Pencegahan Toksoplasmosis Di Wilayah Kerja Puskesmas Blahbatuh I. Archives Nol 6 No 1 (2019): Juni 2019

Aryani, I. G. A. D. (2017). Toksoplasmosis Kongenital. Cermin Dunia Kedokteran, 44(8), 537-539.

Basri, S. (2017). Toksoplasmosis Okular Kongenital. Jurnal Kedokteran Syiah Kuala, 17(2), 133-139.

De La Luz Galvan-Ramirez, M., Troyo, R., Roman, S., Calvillo-Sanchez, C., \& Bernal-Redondo, R. (2012). A systematic review and metaanalysis of Toxoplasma gondii infection among the Mexican population. Parasites \& vectors, $5(1), 1-12$.

Fatmawati, T. Y. (2017). Pengaruh pendidikan kesehatan dengan media leaflet terhadap pengetahuan ibu tentang penatalaksanaan ISPA pada balita di posyandu. Jurnal IImiah Universitas Batanghari Jambi, 17(3), 227234.

Febianingsih, N. P. E., Indriani, C., \& Artama, W. T. (2017). Seroprevalensi Toksoplasmosis di Kabupaten Gianyar, Bali. Berita Kedokteran Masyarakat, 33(2), 61-66.

Guspita, H. (2019). Efektivitas Promosi Kesehatan menggunakan Metode Ceramah tentang HIVIAIDS terhadap Pengetahuan dan Sikap Remaja di SMK Tritech Informatika dan SMK Namira Tech Nusantara Medan tahun 2016. Jurnal IIman: Jurnal IImu Manajemen, 5(1).

Iskandar, T. O. L. I. B. I. N. (2014). Pencegahan Toksoplasmosis Melalui Pola Makan dan Cara Hidup Sehat. JITV, 19(3).

Iskandar, A., Mayashinta, D. K., \& Indra, M. R. (2018). Mengenal Toxoplasma Gondii, Obesitas, dan Sindrom Metabolik. Universitas Brawijaya Press.

Jatmiko, S. W., Romanda, F., \& Hidayatulloh, M. A. A. (2018). Pengaruh Penyuluhan Metode Ceramah dalam Meningkatkan Pengetahuan Masyarakat terhadap Penyakit Tuberkulosis. Jurnal Litbang Sukowati: Media Penelitian dan Pengembangan, 2(1), 1-7.
Kurniawan, B., Suwandi, J. F., \& Arniamantha, D. Perbedaan Tingkat Pengetahuan dan Sikap Ibu Hamil Tentang Toksoplasmosis

Laboudi, M., El Mansouri, B., \& Rhajaoui, M. (2014). The role of the parity and the age in acquisition of Toxoplasmosis among pregnant women in RabatMorocco. International Journal of Innovation and Applied Studies, 6(3), 4.

Lubis, Z. (2016). Pengaruh Penyuluhan Dengan Menggunakan Metode Ceramah Dan Metode Diskusi Terhadap Pengetahuan dan Sikap Ibu Tentang Pemberian Makanan Pendamping ASI (MP-ASI) Di Desa Bintang Meriah Kecamatan Batang Kuis Tahun 2016.

Marthalia, W,. (2020). Chronic Toxoplasmosis Infection in Members of Cat Breeding Organization in Surabaya. Jurnal Kesehatan Lingkungan, 12(1), 48-58.

Notoatmodjo, S. (2003). Pendidikan dan perilaku kesehatan.

Oktariana, A. W,. (2014). Faktor Risiko Terhadap Kejadian Toksoplasmosis Pada Wanita Usia Subur Di Rsu Assalam Gemolong Kabupaten Sragen (Doctoral dissertation, Universitas Muhammadiyah Surakarta).

Runtukahu, A. T., Marunduh, S. R., \& Polii, H. (2021). Peran Imunitas Seluler Pada Ibu Hamil. eBiomedik, 9(2).

Sari, N. L. J. W., \& Sudarmaja, I. M. (2017). Gambaran Tingkat Pengetahuan Remaja Putri Terhadap Toksoplasmosis Di SMA 2 Denpasar Tahun 2014. E-Jurnal Medika, 4(1), 1-9.

Sari, R. D. P. (2019). Kehamilan dengan Infeksi TORCH. Jurnal Kedokteran Universitas Lampung, 3(1), 176-181. Supriati,. 2016. Pengaruh Penyuluhan Dengan Metode Ceramah Dan Metode Diskusi Terhadap Pengetahuan Dan Sikap lbu Tentang Pemberian Makanan Pendamping Asi (MpAsi) Di Desa Bintang Meriah Kecamatan Batang Kuis. http://repositori.usu.ac.id/bitstream/handle.

Smereka, J., Szarpak, L., Ruetzler, K., Schacham, Y., Smereka, A., Dabrowski, M., \& Adam, I. (2018). A multicenter survey on toxoplasmosis knowledge among pregnant women in Poland (the TOWER study). BMC pregnancy and childbirth, 18(1), 1-5.

Suparman, E. (2012). Toksoplasmosis dalam kehamilan. Jurnal Biomedik: JBM, 4(1). 
JKM (Jurnal Kebidanan Malahayati),Vol 7,No.3.Juli 2021,

ISSN (Print) 2476-8944 ISSN (Online) 2579-762X, Hal 391-397

Triana, A. (2015). Faktor Determinan Toksoplasmosis Pada Ibu Hamil. Kemas: Jurnal Kesehatan Masyarakat, 11(1), 25-31.

Wijaya DS ,. 2016. Penerapan Model Student Teams Achievement Division (Stad) Dan Metode Ceramah Terhadap Peningkatan Prestasi Belajar Ips Pada Siswa Kelas V SD Negeri 1 Rajabasa Raya Bandar Lampung.

Wulandari, T. S., Anisah, R. L., Fitriana, N. G., \& Purnamasari, I. (2020). Pengaruh Pendidikan Kesehatan Dengan Media Leaflet Untuk Meningkatkan Pengetahuan Dan Perilaku Dalam Upaya Menerapkan
Protokol Kesehatan Pada Pedagang Di Car Free Day Temanggung. Jurnal IImiah Kesehatan, 10(2), 6-15.

Yan-Li, G., Yi-Qing, X., Yong-Gen, Z., Da-Cheng, X. U., Wen-Wei, X. U., Yang, D., \& MingXue, S. (2017). Infection status of Toxoplasma Gondii and its related knowledge and behavior among special population in Changzhou City. Zhongguo xue xi chong bing fang zhi za zhi= Chinese journal of schistosomiasis control, 29(4), 498-501. 